\title{
Formation of Ethylene by Escherichia coli
}

\author{
By S. B. PRIMROSE \\ Department of Biological Sciences, University of Warwick, Coventry $\mathrm{CV}_{4} 7 A L$
}

(Received 8 December 1975; revised 9 February 1976)

\begin{abstract}
SUMMARY
Escherichia coli strain SPA o converts methionine to ethylene by an inducible enzyme system. L-Cysteine, L-homocysteine, methionine derivatives and the sulphur-containing analogues of L-methionine also act as precursors of ethylene. Ethylene is produced by cell suspensions only in the presence of air; cell-free preparations can produce ethylene aerobically and anaerobically, but the extent to which they do so depends on the mode of culture growth. Light stimulates ethylene production by cell suspensions and its presence is essential for production by cell-free preparations. The kinetics of ethylene biogenesis and its $\mathrm{pH}$ and temperature optima suggest that ethylene is a secondary metabolite.
\end{abstract}

\section{INTRODUCTION}

Soils incubated anaerobically at field moisture capacity produce hydrocarbons, including ethylene (Smith \& Russell, I969; Smith \& Restall, I97I), a gas with marked hormone action on plants. Since ethylene is produced when green plants are absent, but not when soils are autoclaved, the agents producing it are most probably micro-organisms. Lynch (1972) showed that specific substrates could be important for ethylene production in the soil and that addition of glucose and methionine stimulated ethylene production. This led to the isolation of two yeasts and Mucor hiemalis, all of which produced ethylene in pure culture. Subsequently Primrose \& Dilworth (1976) isolated ethylene-producing bacteria from soil around wheat plants damaged by waterlogging. Two of the isolates were identified as Escherichia coli and an examination of a large number of $E$. coli strains yielded one strain SPA $O$, which is a superior ethylene producer.

Ethylene is a common metabolic product of higher plants (Pratt \& Goeschl, 1969) and fungi (Ilag \& Curtis, 1968). Although ethylene biogenesis is associated with the Krebs cycle in Penicillium digitatum, methionine is established as the precursor of ethylene in higher plants (Yang, 1974) and $M$. hiemalis (Bird \& Lynch, 1974). At present there is no proven mechanism of ethylene biosynthesis from methionine but the existence of ethylene-forming bacteria of the enteric type should permit mutant isolation and pathway analysis. As the genetic systems of enteric bacteria are so well understood, the regulatory systems for ethylene biogenesis should be identifiable, thus providing an insight into the control of secondary metabolism in bacteria. As a preliminary to such investigations, this report discusses some factors which affect ethylene production by $E$. coli strain SPA $O$. 
METHODS

Organism and culture medium. Escherichia coli SPA o was from the University of Warwick culture collection. For all experiments, the defined medium of Brown \& Dilworth (1975) was used. Nitrogen was added as ammonium acetate $\left(275 \mathrm{mg} \mathrm{l}^{-1}\right)$, and carbon as glucose $\left(4^{\circ} \circ \mathrm{g}^{-1}\right)$. For nitrogen-limited continuous cultures, the concentration of ammonium acetate was reduced to $70 \mathrm{mg} \mathrm{l}^{-1}$. When nitrate was used as a terminal electron acceptor, the medium was supplemented with $\mathrm{KNO}_{3}$ at $2 \cdot 0 \mathrm{~g} \mathrm{l}^{-1}$. All chemicals were from Sigma.

Growth in sealed flasks. Liquid cultures $(20 \mathrm{ml})$ were grown in $250 \mathrm{ml}$ conical flasks which had ground-glass necks and were fitted with standard turnover-type rubber bungs (SubaSeal; Wm Freeman \& Co., Barnsley, Yorkshire). To avoid ethylene release, the bungs were sterilized in alcohol. Except where stated, light was excluded from all cultures by wrapping the flasks in heavy-duty aluminium foil prior to incubation. When anaerobic conditions were required, the flasks were gassed for about $10 \mathrm{~min}$ with oxygen-free nitrogen.

Growth in chemostat. A I.5 1 fermenter, working vol. I 1 (Western Biological Equipment, Sherbourne, Dorset) was used. Cultures were normally maintained under nitrogen limitation at $30^{\circ} \mathrm{C}$ and $\mathrm{pH} 7 \cdot 2$, at a dilution rate of $0 . \mathrm{I} \mathrm{h}^{-1}$. Except where stated, light was excluded from the chemostat.

Assay of ethylene. Gas samples ( $\mathrm{I} \mathrm{ml}$ ) were withdrawn from the sealed flasks and analysed using a Pye Series I04 gas chromatograph (Pye Unicam, Cambridge) with a flame ionization detector, a $\mathrm{I} \cdot 6 \mathrm{~m} \times 6 \mathrm{~mm}$ column of Porapak R (Phase Separations, Queensferry, Flintshire) at $85^{\circ} \mathrm{C}$, and a nitrogen carrier gas flow of $40 \mathrm{ml} \mathrm{min}{ }^{-1}$.

Concentrations of ethylene in the fermenter effluent gas were much lower than those in flask cultures, so the ethylene produced in the fermenter was absorbed and concentrated by the method of Lynch \& Harper (1974).

Cell-free preparations. Cells were removed from samples of culture $(20 \mathrm{ml})$ by centrifuging, and the resulting supernatant fluid was sterilized by filtration.

\section{RESULTS}

\section{Production of ethylene from $\mathrm{L}-$ methionine.}

When L-methionine was added to batch cultures of $E$. coli SPA o, detectable ethylene production occurred within $\mathrm{I} \mathrm{h}$ and continued for at least $7 \mathrm{~h}$ (Fig. I). Control cultures incubated in the absence of methionine failed to produce detectable amounts indicating that methionine has a role in ethylene formation by $E$. coli. It has been reported (Lynch, 1974) that methionine in solution can decompose to yield ethylene, but any such chemical production must be minimal compared with biological production since no ethylene could be detected over the duration of the experiment when methionine was added to cell-free filtrates (Fig. I). Furthermore, when protein synthesis was inhibited, by the addition of chloramphenicol simultaneously with the L-methionine, no ethylene was detected. However, addition of chloramphenicol $\left(50 \mu \mathrm{g} \mathrm{ml}^{-1}\right)$ to cultures already producing ethylene had little effect over a $7 \mathrm{~h}$ period, suggesting that the enzymes for ethylene formation are induced by L-methionine or a metabolite of L-methionine.

A variety of compounds was tested as alternative substrates for ethylene production but only L-cysteine, L-homocysteine, methionine derivatives, and the sulphur-containing analogues of L-methionine acted as precursors of ethylene (Table I). 
Table I. Ethylene formation from methionine analogues and precursors

$\begin{array}{lclr}\text { Substrate } & \begin{array}{c}\text { Ethylene } \\ \text { produced } \\ \text { (nmol/72 h) }\end{array} & \text { Substrate } & \begin{array}{c}\text { Ethylene } \\ \text { produced } \\ (\mathrm{nmol} / 72 \mathrm{~h})\end{array} \\ \text { L-Methionine } & \mathrm{II} 76 & \text { DL-Methionine (hydroxy analogue) } & \mathbf{1 3 2 0} \\ \text { D-Methionine } & 860 & \text { L-Norleucine } & 0 \\ \text { L-Ethionine } & \mathrm{I} 260 & \text { L-Ketobutyric acid } & 0 \\ \text { L-Cysteine } & 1003 & \text { L-Ketoglutaric acid } & 0 \\ \text { 2-Keto-4-mercaptobutyric acid } & 106 \mathrm{I} & \text { Succinate } & 0 \\ \text { L-Homocysteine } & 1085 & \text { Serine } & 0 \\ \text { L-Formylmethionine } & 7 \mathrm{I} 6 & \text { L-Aminobutyric acid } & 0 \\ \text { L-Methionine methyl ester } & 1452 & & \end{array}$

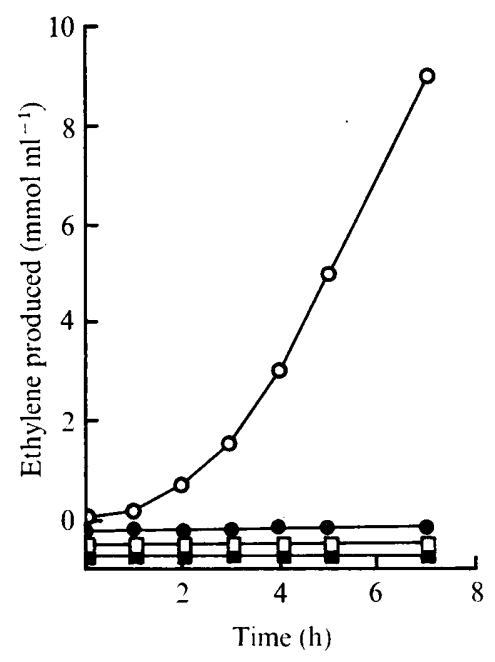

Fig. I

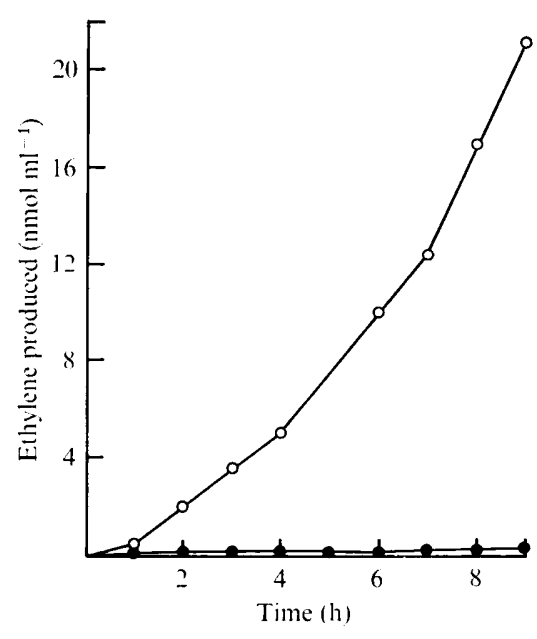

Fig. 2

Fig. I. Production of ethylene by $E$. coli SPA o incubated aerobically in the dark in batch cultures, with the following additions: 0 , none; $\bigcirc$, methionine $\left(500 \mu \mathrm{g} \mathrm{ml}^{-1}\right) ; \mathbf{\square}$, methionine $\left(500 \mu \mathrm{g} \mathrm{ml}^{-1}\right)$ + chloramphenicol $\left(50 \mu \mathrm{g} \mathrm{ml}^{-1}\right)$. $\square$, Ethylene production by a cell-free filtrate with added methionine.

Fig. 2. Effect of oxygen on ethylene production by $E$. coli grown in batch culture in the dark. $\mathrm{O}$, Aerobic incubation; 9 , anaerobic incubation.

\section{Factors affecting ethylene production by strain SPA $\mathrm{O}$}

Substrate concentration. By measuring the initial rate of ethylene production at different substrate concentrations, a value of $6 \mathrm{~mm}$ for the overall $K_{\mathrm{m}}$ was obtained from a doublereciprocal plot. Concentrations of $\mathrm{L}$-methionine higher than $\left.\mathrm{I} 2 \mathrm{mM}(\mathrm{I} \mathrm{mg} \mathrm{ml})^{-1}\right)$ were inhibitory.

Temperature and $\mathrm{pH}$. The optimum temperature and $\mathrm{pH}$ for ethylene production were $30^{\circ} \mathrm{C}$ and $\mathrm{pH} 6.0$, whereas for growth they were $37^{\circ} \mathrm{C}$ and $\mathrm{pH} 7.5$.

Oxygen. When cells which had been grown aerobically in the presence of methionine were incubated anaerobically, ethylene production ceased (Fig. 2) and did not recommence within $9 \mathrm{~h}$. Cells which had been grown anaerobically, with nitrate as the terminal electron acceptor, also failed to convert methionine to ethylene.

Light. When light was excluded from cells which had been producing ethylene, the rate of ethylene production decreased (Figs. 3 and 4). This decrease was observed irrespective of 


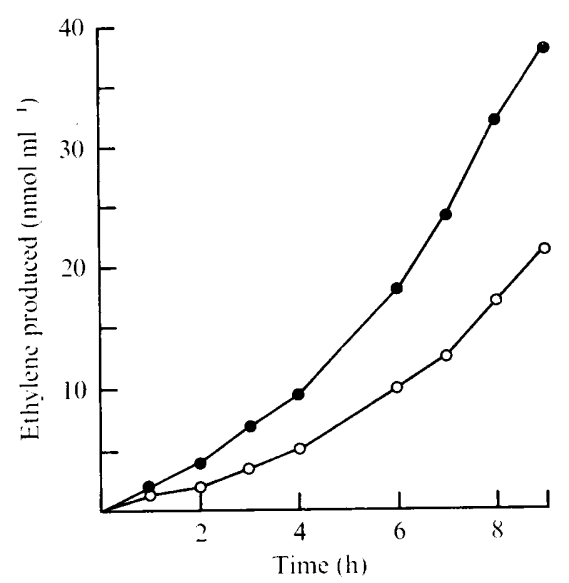

Fig. 3

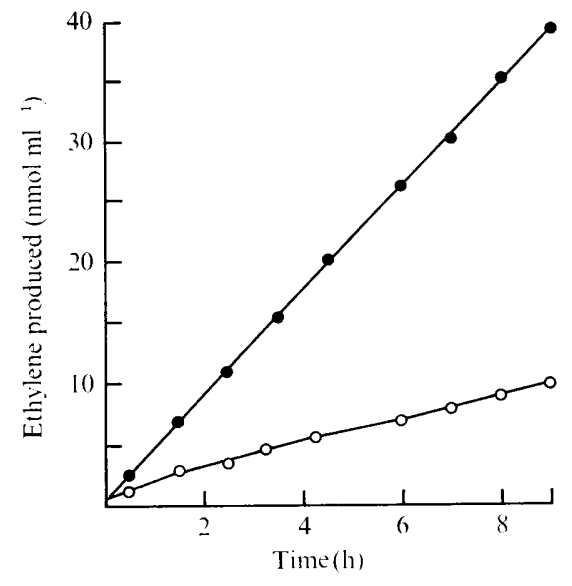

Fig. 4

Fig. 3. Effect of light on ethylene production by $E$. coli grown aerobically in batch culture. $\bullet$, Light present; $\bigcirc$, light absent.

Fig. 4. Effect of light on ethylene production by E. coli grown aerobically in a chemostat. 9 , Light present; $O$, light absent.

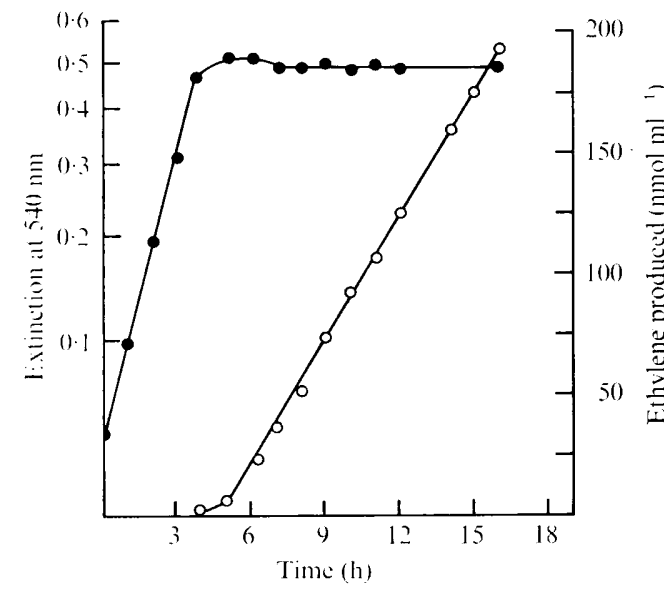

Fig. 5

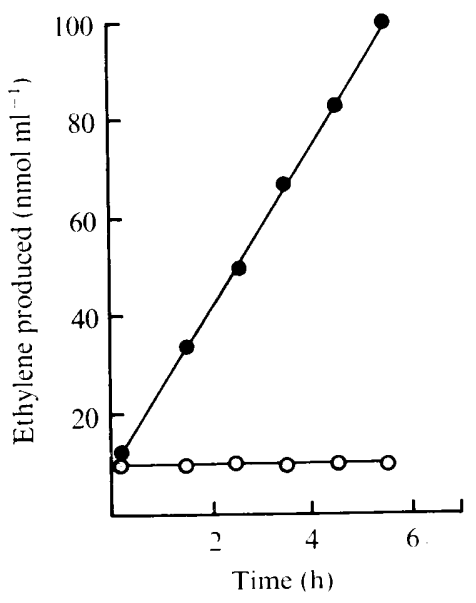

Fig. 6

Fig. 5. Kinetics of ethylene production by $E$. coli grown aerobically in batch culture in the dark. , Extinction at $540 \mathrm{~nm} ; \bigcirc$, ethylene production.

Fig. 6. Effect of light on ethylene production by cell-free filtrates from batch culture incubated aerobically. Light present; $\bigcirc$, light absent. 

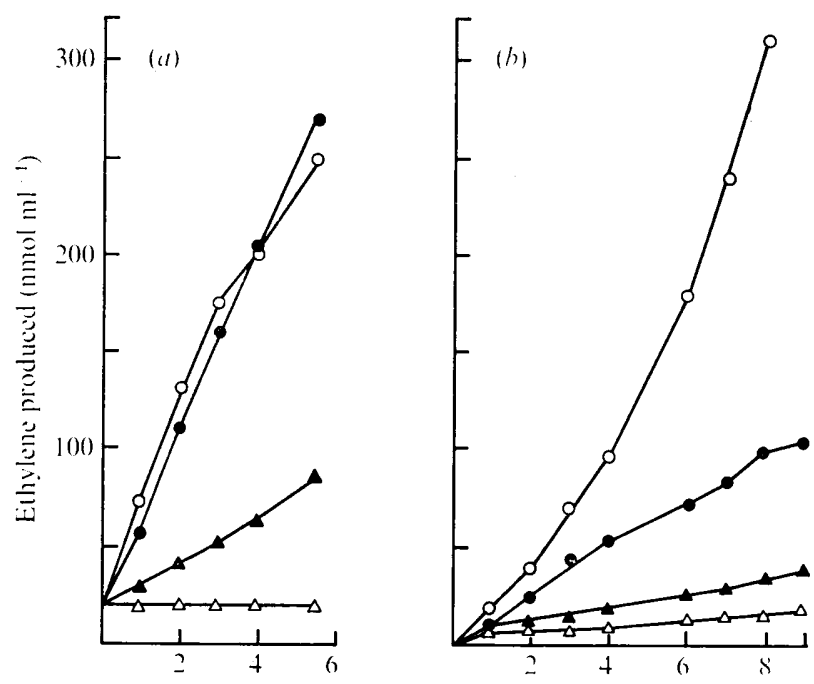

Time (h)

Fig. 7. Effect of growth conditions on ethylene production by cells and cell-free filtrates from cultures grown in the light $(a)$ continuously or $(b)$ in batch culture. $O$, Cells incubated aerobically; $\boldsymbol{0}$, cell-free filtrate incubated aerobically; $\Delta$, cells incubated anaerobically; $\boldsymbol{\Delta}$, cell-free filtrate incubated anaerobically.

the previous history of the culture, but its magnitude depended on whether the cells had been grown in batch culture (Fig. 3) or continuously (Fig. 4). Because of the stimulatory effect of light, cultures were usually incubated in the dark.

\section{Kinetics of ethylene production by batch cultures}

Figure 5 shows the kinetics of ethylene production by $E$. coli SPA o grown in batch culture. Growth reached the stationary phase after 5 to $6 \mathrm{~h}$, and it was at this time that ethylene production was first detected. Production of ethylene increased linearly for over $24 \mathrm{~h}$.

\section{Production of ethylene by chemostat cultures}

Ethylene was produced by chemostat cultures of $E$. coli SPA o which were nitrogen-limited, but not by those which were carbon-limited. Varying the dilution rate between 0.02 and $0 \cdot 2 \mathrm{~h}^{-1}$ had no effect on the rate of ethylene production.

\section{Production of ethylene by cell-free filtrates}

Cell-free preparations from ethylene-producing cultures generated ethylene but the extent to which they did so depended on three factors: (i) the history of the culture, (ii) the presence or absence of oxygen, and (iii) the presence or absence of light. Irrespective of the history of the culture, cell-free filtrates only released significant amounts of ethylene when incubated in the light. Figare 6 shows typical results for cell-free preparations incubated aerobically. Cell-free filtrates also produced ethylene anaerobically (Fig. 7) but only if the culture from which they were derived had been grown continuously in the dark. Little ethylene was produced if the cultures had previously been grown either continuously in the light or in batch culture. 
The rate of ethylene production by cell-free filtrates relative to that of the corresponding cell suspensions depended on the previous cultural conditions. When the culture had been grown continuously in the light or in batch culture, the cell-free preparation produced ethylene at a much slower rate than the corresponding cell suspension (Fig. 7). However, if the cultures had been grown continuously in the dark, similar amounts of ethylene were subsequently produced by cell suspensions and cell-free filtrates. Cell-free filtrates incubated anaerobically in the light always produced more ethylene than the corresponding cultures.

\section{DISCUSSION}

According to Weinberg (I97I), secondary metabolites are natural products without known function in the growth of the producer cells and they are only synthesized after growth ceases. According to this definition ethylene is a secondary metabolite. The data of Fig. 5 indicate that ethylene synthesis does not occur during the exponential phase of growth, and this is confirmed by the observation that the rate of ethylene production in chemostat cultures is independent of the growth rate. Furthermore, since the $\mathrm{pH}$ and temperature optima for ethylene biogenesis are so different from those for growth of $E$. coli, ethylene formation cannot be associated with growth. At present very little is known about the regulation of secondary metabolism in micro-organisms (Demain, 1972), largely because genetic systems are either absent or have not been developed in the organisms studied. Now that a genetically amenable organism such as $E$. coli has been shown to produce a secondary metabolite (ethylene), an insight into the regulation of secondary metabolism may be gained.

Methionine is not the only precursor of ethylene (Table I), but all others so far identified, with the possible exception of ethionine, can be converted to methionine in vivo. Presumably, in the natural environment methionine is the precursor and is produced as a result of decay of organic matter or is released in root exudates. Particularly interesting is the absolute requirement for a sulphur atom in the precursor, as shown by the failure of nonsulphur-containing analogues of methionine, such as norleucine and aminobutyric acid, to be converted to ethylene. It has been suggested (Murr \& Yang, 1975) that the first step in ethylene biogenesis is the conversion of methionine to $S$-adenosylmethionine (SAM). This would explain not only the need for a sulphur atom in the precursor but also the failure of many enteric bacteria to produce significant quantities of ethylene (Primrose \& Dilworth, I976). Since the conversion of methionine to SAM is inhibited by high concentrations of methionine (Hobson \& Smith, 1973; Hobson, 1974) only those mutants with a constitutive SAM synthetase would be capable of producing ethylene. This possibility is currently being examined using mutants resistant to analogues of methionine (Lawrence, Smith \& Rowbury, 1968). The fate of the sulphur and nitrogen atoms of methionine during ethylene biogenesis is not known, but they cannot be assimilated for $E$. coli SPA o fails to grow in a medium in which methionine is the sole sulphur or nitrogen source.

Extracellular preparations of $M$. hiemalis can produce ethylene, but the amount released depends on the mode of culture growth (Lynch, 1974). When growing sealed-flask cultures were filtered and the sterile extracellular preparation re-incubated, the rate of ethylene production was about 60 times greater than in the original culture; the extracellular preparation from chemostat cultures produced about 100 times less ethylene than the original cultures. Extracellular preparations of $E$. coli SPA o also released ethylene but only in the light. In contrast to these observations made with $M$. hiemalis, extracellular preparations obtained from $E$. coli SPA $O$ grown continuously in the dark produced as much ethylene as the original culture; extracellular preparations from batch cultures produced considerably less ethylene than the corresponding culture. 
Lynch (1974) showed that illumination of mixtures of methionine and FAD resulted in ethylene formation. Such an FAD-light system cannot be involved in ethylene formation by $E$. coli, because growing cultures produce significant amounts of ethylene even in the dark, and addition of methionine to culture filtrates does not result in ethylene formation upon illumination. The most logical explanation for the effect of culture history upon ethylene production by cell-free filtrates is that a light-sensitive intermediate is formed. When cells are grown in the dark, this intermediate would accumulate and the rate of ethylene formation would be governed by the rate at which it decomposes in the dark. Cellfree preparations from such dark-grown cultures would contain appreciable amounts of this intermediate, which would decompose to ethylene upon illumination.

The author wishes to thank Mrs V. Waddell for her excellent technical assistance and Professor R. Whittenbury for helpful discussions.

\section{REFERENCES}

BIRD, C. W. \& LYNCH, J. M. (I974). Formation of hydrocarbons by micro-organisms. Chemical Society Reviews 3, 309-328.

Brown, C. M. \& Dilworth, M. J. (1975). Ammonia assimilation by Rhizobium cultures and bacteroids. Journal of General Microbiology 86, 39-48.

Demain, A. L. (1972). Cellular and environmental factors affecting the synthesis and excretion of metabolites. Journal of Applied Chemistry and Biotechnology 22, 345-362.

Hobson, A. C. (1974). The regulation of methionine and $S$-adenosyl methionine biosynthesis and utilization in mutants of Salmonella typhimurium with defects in $S$-adenosyl methionine synthetase. Molecular and General Genetics r31, 263-273.

Hobson, A. C. \& Smith, D. A. (1973). $S$-adenosyl methionine synthetase in methionine regulatory mutants of Salmonella typhimurium. Molecular and General Genetics 126, 7-1 8.

Ilag, L. \& Curtis, R. W. (I968). Production of ethylene by fungi. Science, New York 159, 1357-1358.

Lawrence, D. A., Smith, D. A. \& Rowbury, R. J. (1968). Regulation of methionine synthesis in Salmonella typhimurium mutants resistant to inhibition by analogues of methionine. Genetics 58, 473-492.

LYNCH, J. M. (1972). Identification of substrates and isolation of micro-organisms responsible for ethylene production in the soil. Nature, London 240, 45-46.

LYNCH, J. M. (I974). Mode of ethylene formation by Mucor hiemalis. Journal of General Microbiology 83, 407-4II.

LYNCH, J. M. \& HARPER, S. H. T. (1974). Formation of ethylene by a soil fungus. Journal of General Microbiology 80, I 87-195.

MurR, D. P. \& YANG, S. F. (1975). Inhibition of in vivo conversion of methionine to ethylene by L-canaline and 2,4-dinitrophenol. Plant Physiology 55, 79-82.

Pratt, H. K. \& Goeschl, J. D. (1969). Physiological roles of ethylene in plants. Annual Review of Plant Physiology 20, 54I-584.

Primrose, S. B. \& Dilworth, M. J. (1976). Ethylene production by bacteria. Journal of General Microbiology 93, I 77-I $8 \mathrm{I}$.

Smith, K. A. \& Restall, S. W. F. (1971). The occurrence of ethylene in anaerobic soil. Journal of Soil Science 22, 430-443.

Smith, K. A. \& Russell, R. S. (1969). Occurrence of ethylene, and its significance in anaerobic soil. Nature, London 222, 769-77I.

Weinberg, E. D. (1971). Secondary metabolism: raison d'être. Perspectives in Biology and Medicine r4, $565-577$.

YANG, S. F. (1974). The biochemistry of ethylene: biogenesis and metabolism. In The Chemistry and Biochemistry of Plant Hormones, pp. I 3 I-164. Edited by V. C. Runeckles, E. Sondheimer and D. C. Walton. New York: Academic. 